\title{
PENGARUH TEKHNIK DISTRAKSI BERCERITA TERHADAP NYERI ANAK USIA PRASEKOLAH PADA SAAT PEMASANGAN INFUS DI RUMAH SAKIT GRANDMED LUBUK PAKAM TAHUN 2018
}

\author{
Kardina Hayati ${ }^{1}$, Syatriawati ${ }^{2}$, Arphyta Wahyuni ${ }^{3}$ \\ Institut Kesehatan MEDISTRA Lubuk Pakam \\ Jl. Sudirman No 38 Lubuk Pakam Kab.Deli Serdang, Sumatera Utara. \\ e-mail: kardinahayati@medistra.ac.id
}

\begin{abstract}
The first crisis that often must be faced by child which nursed was hospitalization. One of the frequently performed invasive procedure in children who experienced hospitalization and can result in pain is Blood sampling. Storytelling technic is one of distraction techniques to reduce pain in children is. This research is purpose to get an idea of whether there is the effect of distraction technic on the pain scale storytelling to preschoolers during blood sampling action in the inpatient unit in GrandMed Hospital. This study was experimental with the population of all preschool children aged six years. The samples of this study were eleven control groups and eleven intervention groups. With technique of sampling using purposive sampling technique and analysis used is the $t$ independent. The result showed that there was a significant relationship between storytelling distraction technic against pain scale measure children during blood sampling (value : 0,001; 0,05). Further research was expected to do other models of distraction technic to reduce pain invasive measures such as blood sampling.
\end{abstract}

Keyword: distraction technic, pain scale preschoolers, blood sampling

\section{PENDAHULUAN}

Kegiatan bermain merupakan kegiatan yang menghibur dan disenangi oleh anak-anak. Kegiatan yang menghibur dan menyenangkan dapat membuat anak menjadi lebih sehat dan cerdas. Saat anak bermain secara tidak langsung aktivitas motorik terjadi membuat otot dan tulang anak menjadi lebih aktif bergerak (Wijiyanti, 2015).

Salah satu permainan yang sering dimainkan oleh anak adalah permainan pengalihan perhatian. Permainan pengalihan perhatian sering juga disebut dengan tehnik distraksi. Tehnik ini sering digunakan di rumah sakit khusus untuk menangani anak yang sakit, dimana tehnik ini dilakukan sebagai upaya pengalihan rasa nyeri yang dialami oleh anak disaat sakit.

Bercerita merupakan salah satu tehnik distraksi yang sering diberikan kepada anak sebagai cara untuk mengalihkan pikiran mereka dari rasa sakit maupun takut. Cerita yang diceritakan diambil dari cerita yang biasa diambil kehidupan mereka sehari hari atau film yang disukai oleh anak-anak (Smeltzer and Bare, 2012). 


\section{METODE PENELITIAN}

Gambar 2.1 Kerangka penelitian Tehnik Distraksi Bercerita pada saat pemasangan infus di Rumah Sakit GrandMed lubukPakamTahun 2018.

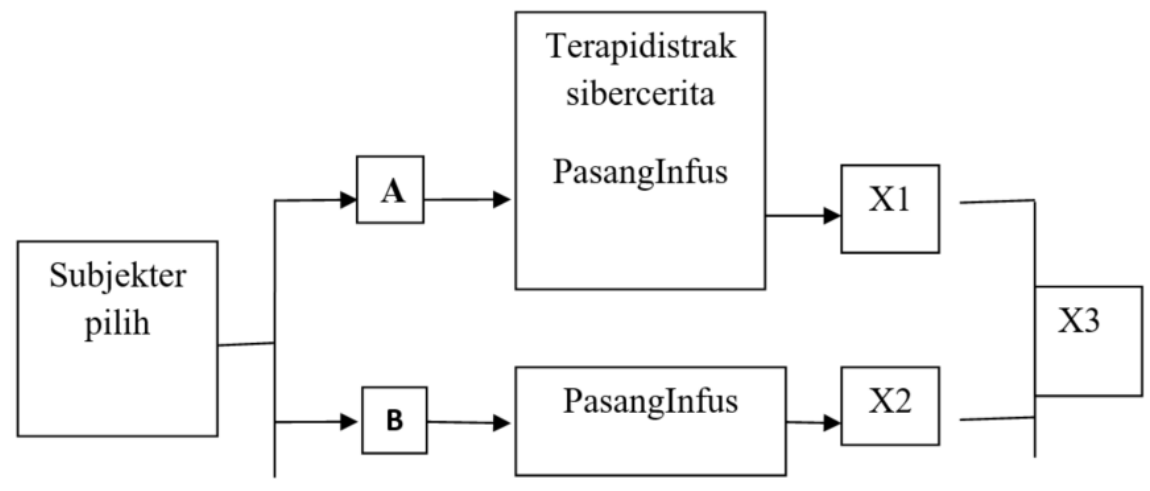

Populasi dalam penelitian ini adalah seluruh pasien anak rawat inap usia prasekolah (6 tahun) di Rumah Sakit Grand Med Lubuk Pakam.

Tehnik pengambilan sampel yang digunakan pada penelitian ini dilakukan dengan menggunakan teknik purposive sampling dengan cara dimana peneliti mengelompokan anggota sampel pada kelompok eksprimen dan kelompok kontrol. Perhitungan besar sampel apabila populasi tidak diketahui maka menggunakan rumus Stanly Lemeshow (Notoatmodjo, 2012).

Rumusbesarsampel (Lameshow)

$$
n=\frac{\mathrm{Z}_{1-\alpha / 2}^{2}\left[\mathrm{P}_{1}\left(1-\mathrm{P}_{1}\right)+\mathrm{P}_{2}-\left(1-\mathrm{P}_{2}\right)\right]}{\mathrm{d}^{2}}
$$

$n$

$$
\begin{gathered}
=\frac{(1,96)^{2}[0,5(1-0,5)+0,5-(1-0,5)]}{(0,15)^{2}} \\
n=10,52=11 \text { Orang }
\end{gathered}
$$

Berdasarkan rumus di atas, maka perkiraan jumlah sampel yang didapatkan sebanyak 11 orang.
Kriteria inklusi pada sampel penelitian ini adalah :

a. Anak usia prasekolah (6 tahun)

b. Anak yang infusnya terlepas saat diruang rawat inap dan akan dilakukan pemasangan infus

c. Anak mampu berkomunikasi secara verbal dengan baik

d. Anak yang mampu mendengarkan dengan baik saat diajak bicara

e. Orang tua atau keluarga bersedia apabila anak menjadi responden penelitian.

Kriteria eksklusi pada sampel penelitian ini adalah :

a. Kondisi anak lemah, gangguan mental, gangguan kesadaran, gangguan pendengaran.

b. Orang tua atau keluarga menolak permintaan jadi responden.

3. HASIL DAN PEMBAHASAN

a. Skala Nyeri Kelompok Kontrol Pada Saat Pemasangan Infus Di Rumah Sakit GrandMed Lubuk Pakam Tahun 2018. 
Berdasarkan hasil penelitian dapat diketahui bahwa responden berjumlah 11 responden dan skala nyeri pada responden yang melakukan pemasangan infus pada kelompok kontrol skala nyeri 0 tidak ada, skala nyeri 1 tidak ada, skala nyeri 2 tidak ada, skala nyeri 3 ada 2 orang (18,2 \%), skala nyeri 4 ada 2 orang $(18,2 \%)$, dan skala 5 ada 7 orang (63,6 \%). Pada hasil penelitian ini menunjukkan bahwa dengan adanya tingkat nyeri yang semakin besar membuat anak usia prasekolah tidak kooperatif dalam melakukan perawatan di ruang rawat inap anak Rumah Sakit GrandMed Lubuk Pakam, hal ini diketahui pada saat peneliti melakukan observasi pada anak yang sedang rawat inap dan akan dilakukan pemasangan infus untuk mendapatkan terapi dari dokter. Kecemasan, ancaman karena ketidaktauan dan ketidakmampua, keletihan, suasana kejadian disekitar anak sering menambah persepsi nyeri. Anak yang sedang mengalami nyeri tetapi mampu mengontrol nyerinya dapat menurunkan persepsi nyeri. Biasanya anak memiliki persepsi kurang kontrol terhadap nyeri atau merasa tidak berdaya sehingga cendrung memiliki persepsi nyeri (Asmadi, 2008).

b. Skala Nyeri Pada Kelompok Intervensi dengan Teknik Distraksi Bercerita Pada Saat Pemasangan Infus Di Rumah Sakit GrandMed Lubuk Pakam Tahun 2018

Berdasarkan hasil penelitian menunjukkan bahwa dari 11 responden skala nyeri 2 ada 8 orang responden ( $72,7 \%)$, skala nyeri 3 ada 3 orang responden ( $27,3 \%$ ) di rumah sakit GrandMed Lubuk Pakam Tahun 2018 pada saat melakukan pemasangan infus dengan perlakuaan tekhnik distraksi bercerita, diketahui dengan lembar observasi yang dilakukan skala nyeri yang di dapatkan lebih kecil dari nilai observasi pada saat pemasangan infus tanpa adanya perlakuan.

$$
\text { Anak dipandu }
$$

membayangkan kondisi yang santai atau tentang pengalaman yang menyenangkan yang dapat mengalihkan rasa nyeri pada anak. Cara ini mampu menurunkan persepsi nyeri dengan menstimulasi sistem kontrol desenden, yang mengakibatkan lebih sedikit stimuli nyeri yang ditransmisikan ke otak (Smeltzer and Bare, 2012).

C. Perbedaan Rerata Nyeri Pada Kelompok Kontrol dan Kelompok Intervensi Yang Dilakukan Pemasangan Infus di Rumah Sakit GrandMed Lubuk Pakam Tahun 2018

Pada data dibawah ini didapatkan nilai rata - rata nyeri pada kelompok kontrol dan rata rata nyeri pada kelompok intervensi yang di lakukan pemasangan infus di Rumah Sakit GrandMed Lubuk Pakam Tahun 2018. Dimana dari kedua kelompok dari setiap hasil yang di dapatkan pada kelompok kontrol dan kelompok intervensi akan di dapatkan nilai mean atau nilai rata - rata pada kedua kelompok pada saat pemasangan infus di Rumah Sakit GrandMed Lubuk Pakam Tahun 2018 dengan menggunakan 
Received: 09 Agustus 2018 :: Revised: 08 September 2018:: Accepted: 10 Oktober 2018

lembar observasi skala nyeri Wong Baker's 0 sampai 5 (Wong, 2012).

Berdasarkan hasil tersebut menunjukkan bahwa nilai rata rata nyeri pada kelompok kontrol pada saat pemasangan infus di Rumah Sakit GrandMed Lubuk Pakam Tahun 2018 dengan jumlah responden pada kelompok kontrol 11 orang dengan nilai rata - rata nyeri 4,18. Pada kelompok intervensi di dapatkan nilai ratarata nyeri pada saat pemasangan infus di rumah sakit GrandMed lubuk pakam tahun 2018 lebih kecil dari kelompok kontrol yaitu 2,82 dari jumlah responden pada kelompok intervensi berjumlah 11 orang.

Berdasarkan Uji statistik yang dilakukan pada saat pengolahan data menggunakan uji independent t test di dapatkan nilai signifikan yang bermakna untuk perbedaan rerata nyeri antara kelompok kontrol dengan rerata nyeri pada kelompok intervensi di Rumah Sakit GrandMed Lubuk Pakam Tahun 2018 pada saat pemasangan infus.

Pada hasil diuraikan bahwa jumlah pada kelompok kontrol ada 11 responden dan kelompok intervensi ada 11 responden yang dilakukan penelitian skala nyeri pada saat pemasangan infus di Rumah Sakit GrandMed Lubuk Pakam Tahun 2018 menunjukkan hasil uji statistik yang dilakukan menggunakan uji independent sampel test di dapatkan hasil $p$ value $=0,001 \quad(p$ value $\leq 0,05)$ maka Ho di tolakdan Ha diterima, jadi dapat diketahui bahwa ada pengaruh Tekhnik Distraksi bercerita Terhadap Nyeri Anak Usia Prasekolah Pada Saat Pemasangan
Infus Di Rumah Sakit GrandMed Lubuk Pakam Tahun 2018.

\section{d. Pengaruh Tekhnik Distraksi Bercerita Terhadap Nyeri Anak Usia Prasekolah Saat Pemasangan Infus Di Rumah Sakit GrandMed Lubuk Pakam Tahun 2018.}

Nilai skala nyeri pada kelompok kontrol dan kelompok intervensi yang dilakukan pemasangan infus di Rumah Sakit GrandMed Lubuk Pakam Tahun 2018. Uji yang digunakan yakni uji Independen Sample Test dimana di ketahui menggunakan nilai $p$ value 0,05 dan hasil uji yang di dapatkan nilaqi $p$ value 0.001 , sehingga dapat disimpulkan bahwasanya ada pengaruh Tekhnik Distraksi Bercerita Terhadap Nyeri Anak Usia Prasekolah Pada Saat Pemasangan Infus Di Rumah Sakit GrandMed Lubuk Pakam Tahun 2018

Berdasarkan hasil diatas menunjukkan bahwa nilai rata rata nyeri pada kelompok kontrol pada saat pemasangan infus di rumah sakit GrandMed lubuk pakam tahun 2018 dengan jumlah responden pada kelompok kontrol 11 orang dengan nilai rata - rata nyeri 4,18. Pada kelompok intervensi di dapatkan nilai rata rata nyeri pada saat pemasangan infus di rumah sakit GrandMed lubuk pakam tahun 2018 lebih kecil dari kelompok kontrol yaitu 2,82 dari jumlah responden pada kelompok intervensi berjumlah 11 orang.Perbedaaan rata -rata nyeri terlihat adanya penurunan ketika rata - rata nyeri tanpa distraksi bercerita dengan adanya tekhnik distraksi bercerita pada saat pemasangan infus dengan rata rata nyeri setelah diberikan tekhnik distraksi bercerita pada 
saat pemasangan infus di Rumah Sakit GrandMed Lubuk Pakam. Penurunan tingkat nyeri pada saat pemasangan infus diakibatkan karena tekhnik distraksi bercerita dapat mempengaruhi eksistensi kerja dari endorfin, dimana endorfin berfungsi sebagai inhibitor terhadap transmisi nyeri dengan memblok transmmisi impuls dalam otak dan medula spinalis (Supartini, 2013).

Berdasarkan hasil penelitian dapat diketahui nilai rata-rata skala nyeri pada kelompok kontrol 4,18 dan nilai rata - rata skala nyeri pada kelompok intervensi 2,82 dengan jumlah responden 11 orang pada kelompok kontrol dan 11 orang pada kelompok intervensi yang dilakukan observasi penilaian nyeri pada saat pemasangan infus di Rumah Sakit GrandMed Lubuk Pakam Tahun 2018, dan hasil uji statistik dapat diketahui nilai $p$ value $=0,001 \quad(p$ value $\leq 0,05)$ maka Ho di tolak dan Ha di terima, jadi dapat diketahui bahwa ada pengaruh tekhnik distraksi bercerita terhadap nyeri anak usia prasekolah pada saat pemasangan infus di rumah sakit GrandMed lubuk pakam tahun 2018. Hal ini sejalan dengan penelitian Kustiningsih, 2012 yang menyatakan ada perbedaan secara bermakna dengan judul tekhnik distraksi musik klasik terhadap intensitas nyeri pada anak usia prasekolah dengan nilai $(p=0,003)$ antara kelompok eksperimen dan kelompok kontrol saat dilakukan pemasangan infus. Teori Gill (1990) yang menerangkan bahwa tingkat seseorang klien memfokuskan perhatiannya pada nyeri dapat mempengaruhi persepsi nyeri. Perhatian yang meningkat dihubungkan dengan nyeri yanng meningkat, sedangkan upaya distraksi dihubungkan dengan nyeri yang menurun. Penurunan tingkat nyeri pada saat pemasangan infus hal ini diakibatkan karena tekhnik distraksi bercerita yang dapat mempengaruhi eksistensi kerja dari endorfin, dimana endorfin berfungsi sebagai inhibitor terhadap transmisi nyeri dengan cara memblok transmisi impuls dalam otak dan medula spinalis (Supartini, 2013). Distraksi yang memfokuskan perhatian klien pada sesuatu selain pada nyeri dapat menjadi strategi yang sangat berhasil dan merupakan mekanisme terhadap tekhnik kognitif efektif lainnya. Distraksi diyakini dapat menurunkan persepsi nyeri dengan menstimulasi sistem kontrol desenden yang mengakibatkan lebih sedikit stimulasi nyeri yang ditransmisikan ke otak (Potter \& Perry, 2012). Salah satu tekhnik distraksi adalah dengan bercerita dimana tekhnik distraksi bercerita merupakan salah satu strategi non farmakologi yang dapat menurunkan nyeri (Sartika, 2015). Pada usia prasekolah anak sudah mampu untuk mengembangkan kreativitas dan sosialisasinya untuk berinteraksi dengan orang lain. Dimana pada dasarnya perkembangan anak prasekolah sebagian besar sudah memiliki keterampilan verbal dan perkembangan yang lebih baik untuk beradaptasi dengan berbagai situasi (Hidayat \& Azimul, 2012).

Pada anak usia 6 tahun berdasarkan teori Piaget bahwa anak - anak bersifat aktif dan merupakan penjelajah yang yang 
Received: 09 Agustus 2018 :: Revised: 08 September 2018:: Accepted: 10 Oktober 2018

selalu ingin tahu. Ketidakseimbangan antara bentuk berfikir anak dan kejadian dalam lingkungan, memaksa anak membuat penyesuain mental yang membuatnya dapat menyelesaikan pengalaman baru yang membingungkan dan kemudian menghasilkan keseimbangan kognitif (Wang, Sun. 2013).

Pada tahap usia 6 tahun dikatakan tahap praoperasional, dimana anak pada tahap ini mengalami peningkatan drastis dalam perkembangan intelektualnya pada penggunaan simbol yaitu kata dan imajinasi untuk menggambarkan benda, situasi, dan kejadian. Namun pada tahap ini anak memiliki keterbatasan dalam menguasai operasi kognitif yang memungkinkan mereka untuk berfikir logis. Anak yang sudah memasuki usia 6 tahun sudah mampu untuk berbahasa lisan seperti berbicara dan bercerita, mampu menguasai keterampilan untuk kebutuhan hidup sehari hari

(mandi, menggosok gigi, berganti pakaian, makan dengan mandiri (Soetjiningsih, 2012).

\section{KESIMPULAN}

Dari hasil penelitian yang dilakukan di Rumah Sakit GrandMed Lubuk Pakam Tahun 2018. Dapat diambil kesimpulan sebagai berikut :

1. Nilai nyeri pada kelompok kontrol yang dialami anak usia prasekolah pada saat pemasangan infus di Rumah Sakit GrandMed lubuk pakam skala nyeri 3 ada 2 orang $(18,2$ $\%)$, skala nyeri 4 ada 2 orang
$(18,2 \%)$, dan skala 5 ada 7 orang $(63,6 \%)$.

2. Nilai nyeri yang dialami pada kelompok intervensi anak usia prasekolah pada saat pemasangan infus di Rumah Sakit GrandMed Lubuk Pakam dengan tekhnik distraksi bercerita di dapatkan hasil nilai pengukuran skala nyeri menggunakan lembar observasi skala 2 ada 8 orang $(72,7 \%)$, skala 3 ada 3 orang (27,3\%), dari jumlah sampel sebanyak 11 orang.

3. Nilai rata - rata nyeri pada kelompok kontrol anak usia prasekolah pada saat pemasangan infus di Rumah Sakit GrandMed lubuk pakam 4,18 dan nilai rata - rata nyeri kelompok intervensi saat dilakukan perlakuan tekhnik distraksi bercerita pada saat pemasangan infus 2,82 .

4. Dari hasil uji statistic yang dilakukan menunjukkan adanya hasil yang bermakna sehingga dapat disimpulkan ada pengaruh tekhnik distraksi bercerita terhadap nyeri anak usia prasekolah pada saat pemasangan infus di rumah sakit GrandMed lubuk pakam tahun 2018.

\section{DAFTAR PUSTAKA}

Asmadi. (2008). Tekhnik Prosedural Keperawatan Konsep dan Aplikasi Kebutuhan Dasar Klien. Salemba Medika. Jakarta . Hal 77

Hidayat, Aziz Alimul, (2013). Pengantar Ilmu Keperawatan Anak .Jakarta : Salemba Medika

Notoatmodjo, Soekidjo. (2012). Metodelogi Penelitian Kesehatan. Jakarta : Rineka 
Received: 09 Agustus 2018 :: Revised: 08 September 2018:: Accepted: 10 Oktober 2018

Potter \& Perry, (2012). Buku Saku: Ketrampilan \& Prosedur Dasar. Edisi 5. Jakarta: EGC

Smeltzer and Bare. (2012)

Sartika, YW (2015). Teknik distraksi dengan bercerita efektif dalam menurunkan nyeri anak usia prasekolah pada pemasangan infus yakni dari nyeri skala 3 ke nyeri skala 2.

Soetjiningsih, (2012). Buku Ajar Tumbuh Kembang Anak, Yogyakarta : Mitra Cendikia

Wang, Sun. (2013). Manajemen Perawatan anak, Yogyakarta : Mitra Cendikia

$\begin{array}{cc}\text { Wong, (2012). } & \text { Pedoman } \\ \text { KlinisKeperawatan } & \text { Pediatrik. } \\ \text { Jakarta : ECG } & \end{array}$

Wijiyanti, (2015). Prevalensi Kesakitan Anak. Diakes di repository.upi.edu

Supartini, Y, (2015). Konsep Dasar Keperawatan Anak DPP PPNI Jakarta : Salemba Medika 